\title{
The Growth Explains its Reasons Itself: From the Retrospect of Bangladesh Economy
}

\author{
Farzana Akter ${ }^{1}$, A.S.M. Habibur Rahman ${ }^{2}$ \\ ${ }^{1}$ Lecturer, Department of Business Administration, East West University, BANGLADESH \\ ${ }^{2}$ Teaching Assistant, Department of Business Administration, East West University, BANGLADESH
}

\begin{abstract}
Bangladesh, a country with a potential economic growth had a rich agro-based economy before $\mathcal{E}$ after its independence. Being one of the most heavily populated countries of the world, it had to face several development challenges. Accelerated growth was just a demand of time that was pushing the whole economy towards Industrial $\mathcal{E}$ Service Sector where growth could be achieved swiftly. This research was performed to portray the structural transition in the economy of Bangladesh after independence. GDP at a constant price was used to represent The Growth of the economy. Step by step, the decomposition method was used to split GDP to the bottom $\mathcal{E}$ to get the most influential sectors $\mathcal{E}$ sub-sectors and their recent trends. The findings from decomposition method were supported by linear regression. A detail $\mathcal{E}$ authentic dataset (42 years) was used to clarify the transition to the economy.
\end{abstract}

Keywords: Growth, GDP, Transition, Bangladesh, Agriculture, Industry, Service

JEL Classification Code: O14, O53

\section{INTRODUCTION}

Bangladesh, a country with prospects \& problem with over population. The war for independence is one of the greatest achievements for Bangladesh, at the same time a chapter of painful struggle. A war results loss of assets, manpower \& economic slowdown which need year after year to recover. From the year after independence this country is achieving a modest average 4\% GDP growth which is appreciable for a war experienced country but not remarkable comparing other neighboring countries. This country always was Agriculture based as it is situated in one of the most fertile lands on earth. But recently it is experiencing a transition from an agrobased economy to an industrial economy like the other East Asian economies who accept that the fastest way for economic growth is greater industrialization.

\section{ECONOMY OF BANGLADESH}

Being situated in a historically prosperous region, Bangladesh always got the advantage of fertile soil \& favorable climate \& turned into an agrarian economy. The latest GDP (Year-2014) of this country is $\$ 116.4$ billion with per capita GDP \$859. Almost more than half of Bangladeshis are directly \& indirectly related with agro sector but in recent time, half of the GDP comes from Service Sector. Garments Industry is the largest contributor of Industrial Sector \& is exporting $80 \%$ of total export that is equivalent to $18 \%$ of total GDP (Sayeed, 2013). Mainly three major sectors- Agriculture, Industry and Service build the economy of Bangladesh. According to Bangladesh Bureau of Statistics,
Agriculture sector includes- Crops \& Horticulture, Animal Farming, Forest \& Related Services and Fishing. Crucial industries are Readymade Garments, Food, Beverage \& Tobacco, Textile, Apparel \& Leather, Wood \& Wood Products, Paper, Paper Product, Printing \& Publications, Chemicals \& Chemical Products, NonMetallic Mineral Products, Basic Metal Industries, Fabricated Metal Products, Jute goods, Other Industries and Handicrafts. Major service providers are Wholesale \& Retail Trade, Repair of Motor Vehicles \& Household Goods, Hotel \& Restaurants, Transport, Storage \& Communication, Monetary Intermediation (Banks), Insurance, Real Estate, Renting \& Business Activities, Education, Health \& Social Works, Community \& Personal Services etc.

\section{LITERATURE REVIEW}

Kamrun Nahar $(2005,2006)$, had shown the actual Real Gross Domestic Product (GDP) and Growth Trend of real GDP in Bangladesh during 1975-2000 (at 1984/85 prices). In her publication she examined the percentage of different sectors (Agriculture, Industry and Service) contribution in GDP and the growth of these three sectors (1981-2004). Agricultural and Industrial GDP are small in those recent years, but Service Sector's GDP was swelling. Abdur Razzaue and Abu Eusuf, (April 2007) discussed about the contribution of RMG sector in GDP of Bangladesh time to time. He also discussed about the lacking and problems of RMG sector and the solution about those problems. A.R. Bhuyan (2012-13), discussed about different sectors and sub-sectors of GDP of 
Bangladesh in detail. He discussed about the problems of Agriculture, Manufacturing, Industry \& Service Sector; and the subsectors under these sectors. The strengths and weakness of different sectors, the solution to the problems \& interrelation among sectors were also shown there. Mohammad Shahidul Islam, Md. Musa, Rajib Kanti Das (2012) analyzed that the contribution of Service Sector was about 50 percent of the total GDP. So, the growth rate of GDP depends on the Service Sectors. The Service Sector provides the support for the development of Industry Sector and Agriculture Sector. The manufacturing sector is growing rapidly. Therefore, the Bangladeshi people need more extensive financial services and technical education in future. Tourism, Hotel Service \& Management have potentiality in Bangladesh.

\section{ObJectives OF THE Study}

The broad objective of this study is to understand the economy of Bangladesh properly. Then we can narrow down some specific objectives also:

- To portray the GDP growth of Bangladesh.

- To examine the contributing sectors \& sub-sectors to the growth of GDP of Bangladesh.

- To depict the sectoral transition in the economy of Bangladesh.

- To elucidate the relationship between Total GDP Growth and sectors \& sub-sectors growth.

\section{SignificANCE OF THE STUdY}

Bangladesh is blessed with natural assets \& workforce. However, our assets are not sufficient to serve this huge population. To meet the demand of the people and to ensure a glorious future for our country, we have to use our assets \& workforce effectively so that we can convert them to wealth. However, this is not an easy task at all. At first, we have to understand our country \& economy. In this study, we tried to perceive our country \& its economy from the angle of GDP (Gross Domestic Product). We have other literatures that have covered either the analysis of three major sectors (Agriculture, Industry \& Service) of GDP or any individual sector. Some of those have limited dataset. Therefore, we feel the urge to analyze the GDP of Bangladesh to the bottom covering data from independence to present. This study desires to reveal all the sources of value addition \& deduction by decomposing the GDP, so that we can use our strengths to utilize the opportunities \& rectify our weaknesses to fight back all the threats.

\section{Methodology}

In this paper, secondary data was used which was collected from various secondary sources such as Statistics Department of Bangladesh Bank, \&Bangladesh Bureau of Statistics (BBS). Among the variables, GDP at a constant price/ Real (Inflation adjusted) GDP was used which is more appropriate to this kind of analytical works. Then sector wise GDP \& Sector wise Export were used to clarify the subject matter of the paper. The data range was from the year 1972 to 2014 for all the variables. Microsoft Excel was used to derive these statistical applications: - Bar Diagram, Line Chart, Area Chart, Regression Analysis \& Correlation Analysis

\section{LIMITATION OF THE STUDY}

We could not collect the secondary data before 1972 \& onwards. In pre \& post war period, it is quite usual to have indiscipline \& disorder in every phase of a country, so we were unable to find any organized \& authentic information.

\section{DECOMPOSITION OF GDP}

One of the purposes of this paper was to tress out the economic growth of Bangladesh. GDP (Gross Domestic Product) was used to represent the economic growth, as it is one of the most familiar indicators. The pattern of GDP growth helps us to understand any country's economic progress or failure. In this paper, GDP at a constant price that is also called inflation adjusted real GDP was used to portray the economic growth \& transition from the post-war period to present.

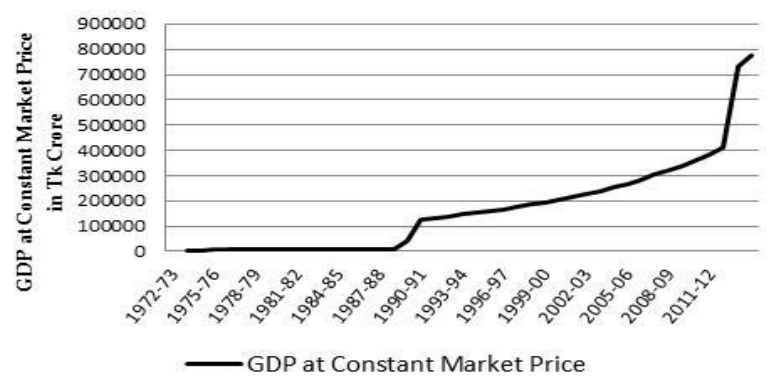

Fig. 1(a): GDP at Constant Market Price (1972-2014)

Source: Bangladesh Bureau of Statistics

From the above line chart, we can clearly understand that in 1972, the GDP was at its lowest, only Tk.4405.1 crore, which is expected for a recent war experienced country \& called the "Darkest time of the History of Bangladesh". The liberation war of 1971 washed out about $20 \%$ of Bangladesh's economy, which was the reason of the very slow progress up to 1989 (The Economist, 2012). After that from 1990 the economy improved a little bit \& was showing a growth. After 90 's the GDP growth rate was on an average more than $4 \%$ due to export growth, increase in public \& private savings, and growth in small \& medium industries \& many other reasons. Then in 2010, it started rising \& had an average growth rate of more than $6 \%$ till now. It is visible from the graph that Bangladesh economy is advancing with a gradual but stable GDP growth. 


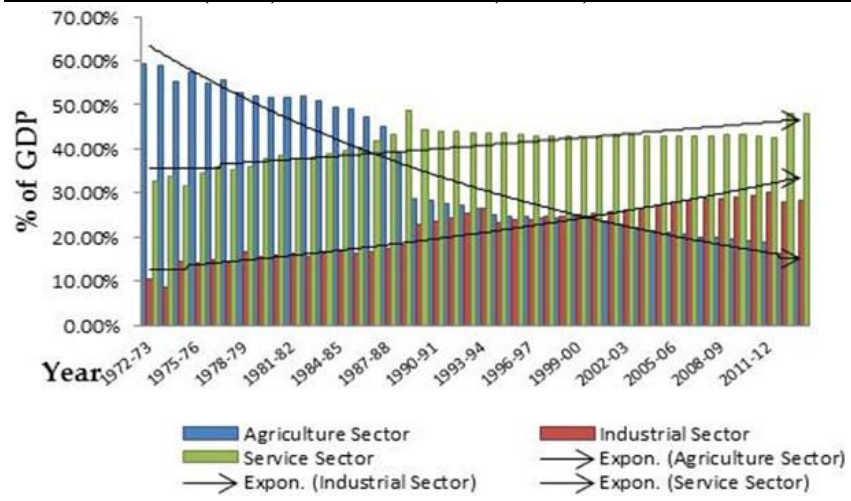

Fig. 1(b): Sector-wise \% share of GDP (1972-2014)

Source: Bangladesh Bureau of Statistics

In this graph, GDP at a constant price is broken down into three major sectors- Agriculture, Industry and Service. The blue bars indicating the percentage share of Agriculture Sector, the red bar is representing the percentage share Industrial Sector \& the green bar is pointing out the percentage share of Service Sector. Traditionally Bangladesh is an agro-based country that is clearly understandable from this figure where from 19721973 to 1984-1985 Agriculture Sector dominated the GDP by contributing more than $50 \%$ share. Afterwards, it started declining below $50 \%$ then moving gradually it was almost $16 \%$ only in the year 2013-2014. On the contrary, Industrial Sector, represented by red bars, started with 10\% share of GDP in the year 1972-1973 \& reached to almost $28 \%$ in 2013-2014. Finally the green bars representing the Service Sector, commencing with $33 \%$ share of GDP in 1972-1973 \& in the year 2013-2014 it was almost $48 \%$. The sectoral distribution of the GDP in this figure is showing us that the economy of Bangladesh is gradually shifting from its traditional Agriculture Sector to Industrial \& Service Sector. In fact, in the last ten years, the Agriculture Sector's average share of GDP was close to or below 20\%, whereas the Service Sector ten years average contribution to GDP was more than $40 \%$ or close to $50 \%$. Now a day, this phenomenon is very common to all the developing countries.

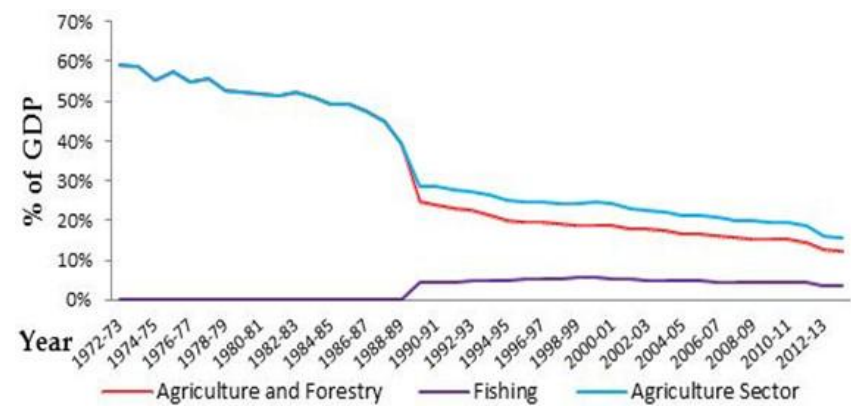

Fig. 2(a): Decomposition of Agriculture Sector \% share of GDP (1972-2014)

Source: Bangladesh Bureau of Statistics
This breakdown is pointing out, from where value addition was coming. Agriculture Sector composed of mainly two sub-sectors- Agriculture \& Forestry and Fishing. From 1972-1973 fishing was considered under Agriculture \& Forestry but with the growing contribution towards GDP it was considered as a separate account from 1989-90. However, the main value addition was coming from Agriculture \& Forestry. In $1972-73,60 \%$ of GDP was supplied by this source but with the pace of time, this contribution was started to decline slowly. In the year 1994-95, 20\% of total GDP \& in $2013-14$, only $12 \%$ of total GDP was provided by this sector. We can experience a growth in fishing, $0 \%$ share in 1972 to $3.5 \%$ share in 2014 . So overall, we can say that low-level value addition from Agriculture \& Forestry results in the declining share of GDP in the Agriculture Sector.

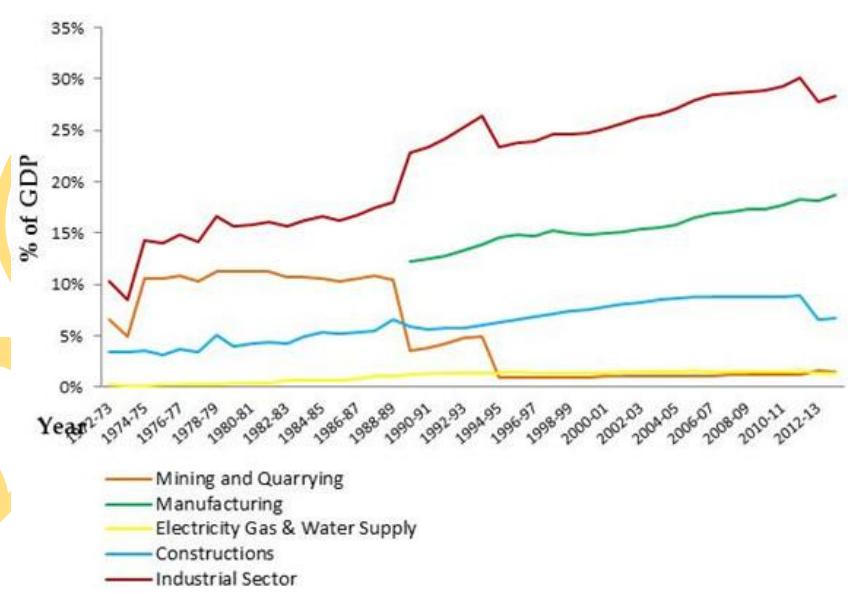

Fig. 2(b): Decomposition of Industrial Sector \% share of GDP (1972-2014)

Source: Bangladesh Bureau of Statistics

This dissection clarifies the specific sources from the Industrial Sector, which contributes mostly in GDP. From the graph, we can find four major sources of Industrial sector- Mining \& Quarrying, Manufacturing, Electricity Gas \& Water Supply and Construction. Previously Mining \& Quarrying and Manufacturing were considered as a single source but after 1988-89, as it was growing massively, GDP from Manufacturing was separated \& recorded individually. From the decomposition, we find that from 1972 to 1988-89 most of the value addition of Industrial Sector was coming from Mining \& Quarrying, on an average 10\% share of GDP. From 1989-90, when Manufacturing was divided, Mining \& Quarrying was started declining and the value addition was coming from manufacturing, on an average $15 \%$ share of GDP, with the outstanding growth in RMG sector. From 1972 to 2014, Constructions was also a stable source but providing only on an average $6 \%$ share of GDP. Electricity, Gas \& Water Supply accounted only average $1 \%$ share of GDP throughout the years. 


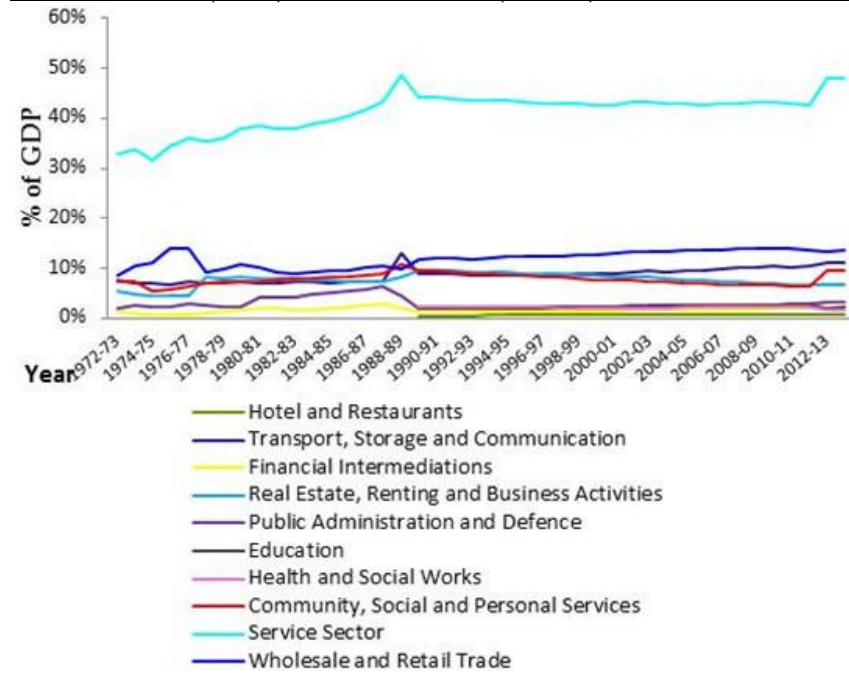

Fig. 2(c): Decomposition of Service Sector \% share of GDP (1972-2014)

Source: Bangladesh Bureau of Statistics

From the graph, we can find nine sources in the Service Sector. Among them, from 1972 to 2014, Wholesale \& Retail Trade Sector contributed most, on an average $12 \%$ share of GDP. Then Transport \& Communication, Real Estate and Community Social \& Personal Services provided to on an average $9 \%, 8 \% \& 8 \%$ share of GDP consecutively, from 1972 to 2014. However, Transport \& Communication was growing steadily but Real Estate and Community \& Personal Services had a decreasing contribution trend. Other sources were also contributing, on an average 2\%-3\% from 1972 to 2014 . From the above discussion we find, Wholesale \& Retail Trade, Transport, Real Estate and Community \& Personal Services were the key provider of value addition from Service Sector.

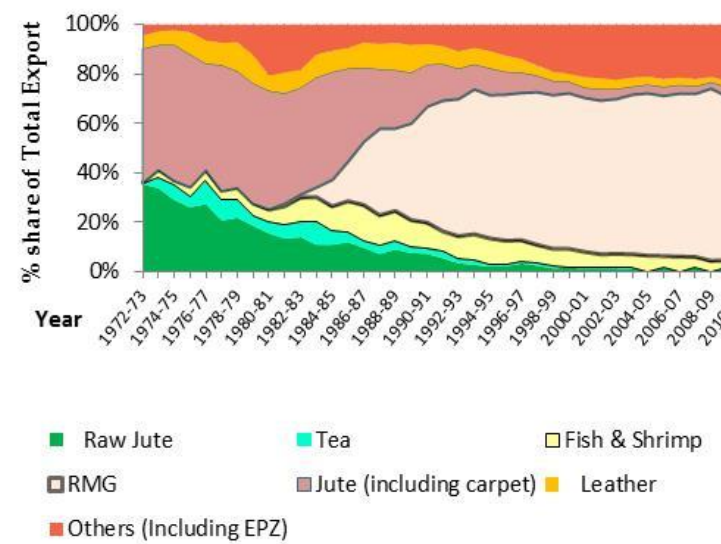

Fig. 3: Sector-wise Export \% share of Total Export (1972-2014) Source: Statistics Department, Bangladesh Bank

Figure 3 shows the analysis of Export information of Bangladesh from the year 1972 to 2014. To illustrate the economic growth, we have analyzed sector-wise export data from 1972 to 2014 . From the graph, we can find two leading export items, Agriculture \& Industrial product. Bangladesh exports raw jute, tea and fish \& shrimp as agricultural product \& readymade garments, jute goods, leather \& some others export items like chemicals, naphtha etc. under industrial product category. Figure 3 depicts the gradual declining agricultural export area from 1972. In that year agricultural export was $36.14 \%$ of total export but in 2014 it went down to only $2.37 \%$. From the decomposition, it is clear because of low production \& export of raw jute, the export of total agricultural product losing its share of GDP. In 2014, raw jute export was only $0.44 \%$ of the total export whereas it was $35.31 \%$ in 1972 . On the other hand, export of industrial product increased rapidly. In 1972, total industrial export was $64.19 \%$ of total export \& in 2014 it was $97.63 \%$. The ultimate contributor to this super-fast growth of Industrial Sector was exporting readymade garments. The Garments Industry flourished in 1980's, after that, this industry progress was so high that $68.67 \%$ of total export from Bangladesh was provided by this sector alone in 2014. Exporting jute goods was quite a good source to earn foreign currency in 1972. At that time, $54.20 \%$ of total export was provided from this source but in 2014 only $2.5 \%$ was added from this source.

\section{REGRESSION MODEL}

In this section, we want to establish a linear regression model. We have considered, GDP at a constant market price as our dependent variable \& GDP from all the subsectors are considered as the independent variables. Therefore, our model is $\mathrm{Y}=\mathrm{a}+\mathrm{bx}$ where $\mathrm{a}=$ intercept \& $b=$ slope of the equation.

Model summary
\begin{tabular}{|c|c|c|c|c|}
\hline $\begin{array}{c}\text { Independent } \\
\text { Variables }\end{array}$ & Intercept & slope & $\mathbf{R}$ & R square \\
\hline $\begin{array}{c}\text { Agriculture and } \\
\text { Forestry }\end{array}$ & $-45,014.70$ & 7.404 & 0.977 & 0.955 \\
\hline Fishing & $-10,558.30$ & 24.08 & 0.977 & 0.955 \\
\hline $\begin{array}{c}\text { Mining and } \\
\text { Quarrying }\end{array}$ & $13,075.20$ & 53.47 & 0.815 & 0.665 \\
\hline Manufacturing & $21,458.20$ & 5.422 & 0.996 & 0.992 \\
\hline $\begin{array}{c}\text { Electricity Gas \& } \\
\text { Water Supply }\end{array}$ & $3,122.17$ & 67.68 & 0.997 & 0.994 \\
\hline Constructions & $3,596.95$ & 12.84 & 0.983 & 0.966 \\
\hline $\begin{array}{c}\text { Wholesale and } \\
\text { Retail Trade }\end{array}$ & $5,725.78$ & 7.318 & 0.999 & 0.998 \\
\hline $\begin{array}{c}\text { Hotel and } \\
\text { Restaurants }\end{array}$ & $17,028.09$ & 138.8 & 0.998 & 0.996 \\
\hline $\begin{array}{c}\text { Transport, } \\
\text { Storage and } \\
\text { Communication }\end{array}$ & $14,960.36$ & 9.254 & 0.996 & 0.993 \\
\hline
\end{tabular}




\begin{tabular}{|c|c|c|c|c|}
\hline $\begin{array}{c}\text { Financial } \\
\text { Intermediations }\end{array}$ & $56,130.74$ & 33.18 & 0.948 & 0.899 \\
\hline $\begin{array}{c}\text { Real Es tate, } \\
\text { Renting and } \\
\text { Business }\end{array}$ & $-16,763.30$ & 14.31 & 0.991 & 0.981 \\
\hline $\begin{array}{c}\text { Public } \\
\text { Administration } \\
\text { and Defense }\end{array}$ & $19,153.91$ & 32.399 & 0.99 & 0.981 \\
\hline Education & $10,716.90$ & 41.89 & 0.991 & 0.983 \\
\hline $\begin{array}{c}\text { Health and Social } \\
\text { Works }\end{array}$ & $-2,668.74$ & 48.82 & 0.987 & 0.975 \\
\hline $\begin{array}{c}\text { Community, } \\
\text { Social and } \\
\text { Personal Services }\end{array}$ & $17,146.05$ & 11.3 & 0.979 & 0.959 \\
\hline
\end{tabular}

Above information, strengthen our previous analysis that all the subsectors had positive impact on total GDP of Bangladesh. The correlation coefficient $(R)$ revealed that all the independent variables had almost perfectly positive relationship with GDP. Negative intercepts of Agriculture and Forestry, Fishing, Real Estate, Renting \& Business Activities and Health \& Social Works reveal the fact these sectors contribution was declining over the years. $\mathrm{R}$ square discloses that, all the independent variables can explain almost $90 \%$ variation of the $Y$ variable. Though $\mathrm{R}$ square for Mining \& Quarrying was a little bit low, only 0.665 , that means it can explain only $66.5 \%$ variation of the $\mathrm{Y}$ variable. But still it is in an acceptable range.

\section{FINDINGS}

From the reviewed literature, we have come to know that Bangladesh was in a structural shifting. After considering the latest GDP, we have also find out that during the first two decades, economic development was greatly dependent on the Agriculture Sector in Bangladesh. Agriculture \& Forestry was the vital component of this sector. Because of limited land, lagging behind from modern technology this sector's contribution started to decline and so did the total Agriculture Sector. After 1975 for the privatization of public industries, Industry Sector gradually developed and it's still growing and developing. Mining \& Quarrying and manufacturing were the main sources of value addition towards GDP. Economic growth had benefited from strong exports, mainly in the garment exports that was accelerated by international market conditions in textile \& clothing. We are also agreed with our previous researchers that, from 1972-2014 over all the decades Service sector bestowed the largest portion of GDP and it could be said that now Bangladesh economy is service oriented. Wholesale \& Retail trade, Transport,
Real Estate and Community \& Personal Services were the ultimate provider of value addition from Service Sector. Analysis of export information of Bangladesh also supports the same findings that Bangladesh economy was facing a transition from its traditional agricultural sector. The export of Bangladesh was more focused now on Garments Industry \& Chemical rather than Raw Jute \& Jute products. However, if we consider employment of Bangladesh economy, Agriculture sector outperformed the other sectors. In the year $2002-03,51.69 \%$ of total employed persons were involved with Agriculture Sector whereas only $13.54 \%$ were involved with industry \& $34.31 \%$ of total employed persons were related with Service Sector. In 2010, the ratio went to $47.5 \%, 17.56 \%$ and $35.3 \%$ for Agriculture, Industry \& Service Sector consecutively. [Source: Statistical Pocketbook of Bangladesh-2013, Bangladesh Bureau of Statistics]. The employment information reveals one very important thing that how is it possible to have $47.5 \%$ employed persons engaged with a sector but produced lowest GDP! It is possible! We are far from the use of modern technology in our agriculture sector. Poor agricultural education, less financial support from government \& excessive dependency are also some crucial reasons. From the low progress it is easily understandable that both the government \& private sectors keep agriculture sector out of their sight.

\section{CONCLUSION}

All the LDC's are going through the change of structural pattern, a slow but obvious transition from agro-based economy to Industrial or Service based economy. Often some transition is taking place within the industry from low productive sector to high productive sector. Moreover, some industries were interrelated or dependent one over another. Such as Banking \& Insurance, Hotel \& Tourism Industry developed with the increasing demand \& growth of RMG sector. Agriculture, Manufacturing\& construction sector expanded with the help of extensive Banking \& Insurance services. We have nine LDC's in Asia region that are also in the pace of Bangladesh. Better or smaller, most of them are agriculture dependant in terms of value addition, export \& employment. They are struggling to focus on the high productive industrial sectors, but like Bangladesh, these countries employment composition are agriculture based (Bhattacharya, Islam, Salma \& Joki Uddin, 2015). For sustainable growth, every country should have even development in every sector. In case of Bangladesh, it is become a Service oriented economy that could be a matter of concern. If Bangladesh \& other Asian LDC's could bring improvement in Agriculture \& Industrial Sector that will bring better economic future, otherwise a single occurrence could lead to the collapse of the whole economy. Policymaker should formulate policy so that all the sectors could flourish evenly. 
ISSN 2304-2613 (Print); ISSN 2305-8730 (Online)

Reducing corruption, controlling inflation, development of infrastructure, decentralized government, adopting modern technology, supportive incentive policy for farmers, promoting exports, liberal trade policy, supporting weak \& infant industry \& converting population to assets are some of the primary demands of today's growth seeking Bangladesh.

\section{REFERENCES}

Bangladesh Bank,. (2013). Monthly Economic Trends (Time Series Data From 1972) (p. TableIV\&TableXIV). Retrieved from http://.bangladesh-bank.org/econdata/index.php

Bangladesh Bank,. (2015). Monthly Economic Trends (March 2015) (pp. 32,48-49). Retrieved from http://www.bangladeshbank.org/pub/monthly/econtrds/mar15/econtrds.php

Bangladesh Bureau of Statistics. (2013).STATISTICAL POCKETBOOK OF BANGLADESH-2013. (2013) (Latest ed., p. 151). Retrieved from http://www.bbs.gov.bd/WebTestApplication/userfiles/I mage/LatestReports/PB2013.pdf

Barua, S., Mridha, A., \& Khan, R. (2010). Housing Real Estate Sector in Bangladesh Present Status and Policies Implications. ASA University Review, Vol. 4(No. 1).

Bhattacharya, D., Islam, T., Salma, U., \& Joki Uddin, G. (2015). Attaining the MDGs, How Successful are the LDCs? In Dialogue on Delivery of the MDGs in LDCs and Reflections on Post 2015 Issues (p. 8). Dhaka: Friedrich Ebert Stiftung (FES).

Bhuyan, A. (2013). Performance Evaluation of the Bangladesh Economy during FY 2012-13. THOUGHTS ON ECONOMICS, Vol. 23(No. 03).

Garrett, J., \&Chowdhury, S. (2004). Urban-Rural Links and Transformation In Bangladesh: Retrieved from http:/ / www.carebangladesh.org/publication/Publication _8999853.pdf

Hossain, B. (2015). The Effect of Foreign Aid on the Economic Growth of Bangladesh. Journal of Economics And Development Studies, Vol. 2(No. 2).
Islam, A., \&Khatun, F. (2010). Trade Liberalization and the Growth of Transport Services in Bangladesh: An Environmental Impact Assessment Study for Dhaka City. In ARTNeT. Bali, Indonesia. Retrieved from http://artnet.unescap.org/tid/artnet/mtg/reformservice_ bp16.pdf

Islam, M., Musa, M., \& Das, R. (2012). The Comparative Growth of Service Sectors in Bangladesh. Research Journal Of Finance \& Accounting, Vol 3(No. 5). Nahar, K. (2005). An Analysis of Growth Trend and Changing Structure of GDP in Bangladesh (2nd ed.). Retrieved from https://www.muktomona.com/Articles/kamrun_nahar/BD_GDP.pdf

Qamruzzaman, M., \& Ferdaous, J. (2015). Building a Knowledge-Based Economy in Bangladesh. Asian Business Review, 4(3), 41-49. Retrieved from http://journals.abc.us.org/index.php/abr/article/view/ Qamruzzaman

Razzaue, A., \&Eusuf, A. (2007). Trade, Development and Poverty Linkage: A Case Study of Ready Made Garment Industry in Bangladesh. Retrieved from http://www.cutscitee.org/PDF/Bang_RMG.pdf

Sabur, S., Palash, M., Awal, M., \& Rahman, K. (2010). Shrimp export from Bangladesh: Effect of war and trade liberalization. Journal of The Bangladesh Agricultural University, 8(1). doi:10.3329/jbau.v8i1.6409

Sayeed, M. (2013). A Test of Resilience - RMG in Bangladesh. IDLC MONTHLY BUSINESS REVIEW, Vol.9(Issue 5).

The Economist,. (2012). The path through the fields. Retrieved from http://www.economist.com/news/ briefing/21565617-bangladesh-has-dysfunctional-politicsand-stunted-private-sector-yet-it-has-been-surprisingly

Titumir, R., \&Rana, E. (2015). Recent Trends of Growth in Agriculture, Industry and Power. Retrieved from http://unnayan.org/reports/meu/MEU_March_2014/Fin al\%20MEU\%28Edited\%29_29\%20March14.pdf

$$
\text { -- } 0 \text {-- }
$$

